AL IBTIDA: JURNAL PENDIDIKAN GURU MI (2018) VOL 5 (2) : 249-260

DOI: http://dx.doi.org/ 10.24235/al.ibtida.snj.v5i2.3342

\title{
Pengaruh Perkembangan Psikososial Terhadap Hasil Belajar PPKn Siswa Kelas IV MIN Kota Cirebon
}

\author{
Latifah* \\ *Program Studi Pendidikan Guru Madrasah Ibtidaiyah, Fakultas Ilmu Tarbiyah dan Keguruan, \\ IAIN Syekh Nurjati Cirebon \\ Email: latifa252@yahoo.co.id

\section{Dwi Anita Alfiani**} \\ **Program Studi Pendidikan Guru Madrasah Ibtidaiyah, Fakultas Ilmu Tarbiyah dan Keguruan, \\ IAIN Syekh Nurjati Cirebon \\ Email: deamers77@gmail.com \\ Andini*** \\ ***Program Studi Pendidikan Guru Madrasah Ibtidaiyah, Fakultas Ilmu Tarbiyah dan Keguruan, \\ IAIN Syekh Nurjati Cirebon \\ Email: iniandini113@gmail.com
}

Received 05 October 2018; Received in revised form: 12 October 2018; Accepted 13 October 2018 Publish Online: 31 October 2018

\begin{abstract}
Abstrak
Perkembangan psikososial merupakan proses berkembangnya kemampuan anak untuk menyesuaikan diri terhadap dunia sosial yang lebih luas. Perkembangan psikososial seorang siswa yang baik dan terarah akan berdampak terhadap hasil belajar PPKn dari siswa itu sendiri. Karena bagaimanapun psikososial mempunyai peran penting dalam merangsang saraf dan otot untuk mencapai perkembangan psikososial siswa yang baik. Penelitian ini bertujuan untuk: (1) memperoleh data perkembangan psikososial, (2) memperoleh data hasil belajar PPKn di kelas IV B, (3) mengetahui seberapa besar pengaruh perkembangan psikososial terhadap hasil belajar PPKn di kelas IV B MIN Kota Cirebon. Peneliti ini menggunakan pendekatan kuantitatif, dan menggunakan desain penelitian Pre-eksperimental design. Bentuk Pre-eksperimental design dalam penelitian ini adalah desain One-Shot Case Study. Teknik pengumpulan data yang digunakan dalam penelitian ini adalah angket dan tes, angket digunakan untuk memperoleh data perkembangan psikososial dan tes digunakan untuk memperoleh data hasil belajar PPKn. Analisis data menggunakan analisis regresi. Hasil penelitian menunjukan bahwa respon siswa terhadap perkembangan psikososial adalah 59\%, skor tersebut tergolong cukup kuat yang berada di antara 41\% - 60\%. Sedangkan hasil belajar PPKn diperoleh nilai rata-rata sebesar 62,5. Berdasarkan hasil uji regresi diperoleh thitung sebesar 11,029 lebih besar dari tabel sebesar 2,10982 maka $\mathrm{H}_{0}$ ditolak, artinya bahwa ada pengaruh perkembangan psikososial terhadap hasil belajar PPKn. Besar pengaruhnya adalah 87,1\% hasil belajar PPKn dipengaruhi oleh perkembangan psikososial sedangkan sisanya 12,9\% dipengaruhi oleh faktor lain.
\end{abstract}

Kata kunci: perkembangan psikososial, hasil belajar, PPKn 


\begin{abstract}
Psychosocial development is a process of developing a child's ability to adapt to the wider social world. The psychosocial development of a students who is good and directed will have an impact on the learning outcomes of PPKn from the students themselves. Because however psychosocial has an important role in stimulating nerves and muscles to achieve good psychosocial development of students. This study aims to: (1) obtain psychosocial development data, (2) obtain data of learning outcomes of PPKn in class IV B, (3) find out how big influence of psychosocial development on learning result of PPKn in class IV B MIN Kota Cirebon. The researcher uses a quantitative approach, and uses the Preexperimental design research design. The Pre-experimental design in this research is the One-Shot Case Study design. Data collection techniques used in this study were questionnaires and tests, questionnaires were used to obtain psychosocial development data and tests used to obtain data on learning outcomes of PPKn. Data analysis using regression analysis. The results showed that students' responses to psychosocial development were $59 \%$, the score was quite strong amongst $41 \%-60 \%$. While the results of learning PPKn obtained an average value of 62.5. Based on regression test results obtained tcount of 11.029 greater than ttable of 2.10982 then $\mathrm{H} 0$ rejected, meaning that there is influence psychosocial development on learning outcomes PPKn. The greatest effect is $87.1 \%$ of the learning outcomes of PPKn influenced by psychosocial development while the remaining $12.9 \%$ is influenced by other factors.
\end{abstract}

Keywords: psychosocial development, learning outcomes, PPKn.

\title{
PENDAHULUAN
}

Perkembangan tidak terbatas pada pengertian pertumbuhan yang semakin membesar, melainkan di dalamnya juga terkandung serangkaian perubahan yang berlangsung secara terusmenerus dan bersifat tetap dari fungsi-fungsi jasmaniah dan rohaniah yang dimiliki individu menuju ke tahap kematangan (Desmita, 2015). Hal ini dinyatakan dalam surat Al-Mu'min ayat 67, sebagai berikut:

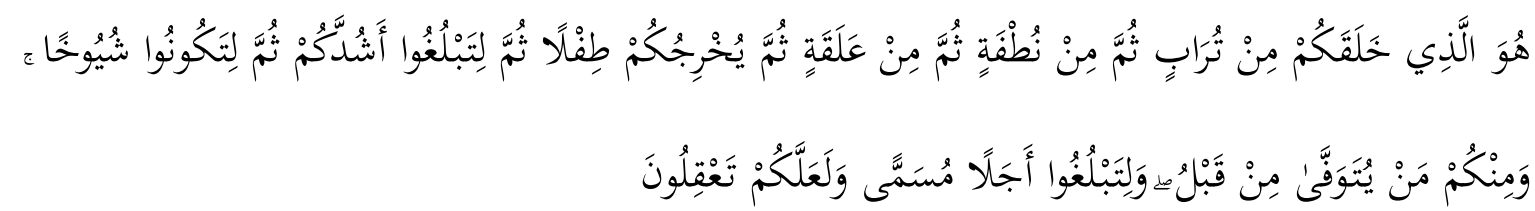

Artinya: "Dia-lah yang menciptakan kamu dari tanah kemudian dari setetes air mani, sesudah itu dari segumpal darah, kemudian dilahirkannya kamu sebagai seorang anak, kemudian (kamu dibiarkan hidup) supaya kamu sampai kepada masa (dewasa), kemudian (dibiarkan kamu hidup lagi) sampai tua, di antara kamu ada yang diwafatkan sebelum itu. (Kami perbuat demikian) supaya kamu sampai kepada ajal yang ditentukan dan supaya kamu memahami (nya)" (QS. AlMu'min: 67). Ayat tersebut menjelaskan tumbuh dan berkembangnya manusia secara bertahap, berawal dari setetes air mani sampai terbentuklah manusia yang sempurna. Perkembangan setiap anak berbeda dan tingkat di mana individu anak-anak tumbuh berbeda. Meskipun pola dan urutan untuk pertumbuhan dan perkembangan biasanya sama untuk semua anak-anak, namun berbeda pada tingkat dimana individu anak mencapai tahap perkembangan (Burhaein, 2017). 
Perkembangan anak-anak usia Sekolah Dasar (SD)/ Madrasah Ibtidaiyah (MI) merupakan perkembangan masa pertengahan dan akhir anak-anak, periode ini berlangsung dari usia 6 tahun hingga tiba saatnya individu menjadi matang secara seksual. Permulaan masa pertengahan akhir anak-anak ini ditandai dengan masuknya anak ke kelas satu sekolah dasar. Pada masa ini mereka mulai sekolah dan kebanyakan anak-anak sudah mempelajari mengenai sesuatu yang berhubungan dengan manusia, serta mulai mempelajari berbagai keterampilan praktis. Dunia psikososial anak menjadi semakin kompleks dan berbeda dengan masa awal anak. Relasi dengan keluarga dan teman sebaya terus memainkan peranan penting dalam perkembangan psikososial (Desmita, 2015).

Perkembangan psikososial adalah proses berkembangnya kemampuan anak untuk menyesuaikan diri terhadap dunia sosial yang lebih luas. Dalam proses perkembangan ini siswa diharapkan mengerti/memahami orang lain yang berarti mampu menggambarkan ciri-cirinya, mengenali apa yang dipikirkan, dirasa, dan diinginkan serta dapat menempatkan diri pada sudut pandang oranglain tersebut tanpa "kehilangan" dirinya sendiri, sehingga akan terciptanya suatu interaksi sosial (Soetjiningsih, 2014). Interaksi sosial yang meliputi interaksi dengan anggota keluarganya, interaksi dengan teman sebayanya, interaksi dengan lingkungan sekolahnya, semua itu merupakan ruang lingkup dari berkembangnya psikologi sosial (psikososial), sesuai dengan pendapat dari Santrock (2011) menyatakan bahwa ketika seorang siswa mengalami perkembangan, mereka sangat memerlukan interaksi dengan orang-orang terdekat yang mereka cintai. Dengan begitu maka akan tercipta rasa percaya diri pada anak sehingga meningkatkan kemampuan dan hasil belajarnya. Hasil belajar tersebut merupakan tolak ukur perlakuan yang diterima siswa baik dari lingkungan keluarga, lingkungan teman bermain, dan lingkungan sekolah berupa hasil belajar.

Hasil belajar siswa yang berbeda-beda merupakan hal yang lumrah di kalangan pendidikan. Pendidikan Pancasila dan Kewarganegaraan (PPKn) merupakan salah satu mata pelajaran yang ada di SD/MI. PPKn memiliki peran sentral dalam perkembangan psikososial di $\mathrm{SD} / \mathrm{MI}$, usia mereka haus akan pengetahuan, sangat penting dan tepat untuk memberikan konsep dasar tentang perilaku secara benar dan terarah, jika salah maka akan berdampak terhadap pola pikir dan perilaku pribadi yang memengaruhi pada jenjang selanjutnya juga pada kehidupan di masyarakat. Pernyataan tersebut sejalan dengan pendapat Susanto (2016) bahwa pendidikan kewarganegaraan adalah mata pelajaran yang digunakan sebagai wahana untuk mengembangkan dan melestarikan nilai luhur dan moral ini diharapkan dapat diwujudkan dalam bentuk perilaku kehidupan siswa sehari-hari, baik sebagai individu maupun anggota masyarakat, dan makhluk ciptaan Tuhan Yang Maha Esa. Harapannya perkembangan psikososial seorang siswa yang baik 
dan terarah akan berdampak terhadap hasil belajar PPKn dari siswa itu sendiri. Kepedulian berupa perhatian dari orang tua, dan lingkungan sekitarnya merupakan kunci motivasi tersendiri yang dapat menumbuhkan keinginan belajar dari dalam diri siswa, adanya sikap peduli dari orang tua terhadap perkembangan psikososial siswa akan berdampak pada hasil belajarnnya di sekolah. Dengan tercapainya aspek perkembangan psikososial tersebut akan membantu siswa untuk mendapatkan hasil yang baik pula.

Kenyataan yang ada berdasarkan hasil observasi di lapangan, siswa memperoleh nilai PPKn yang baik namun tidak mencerminkan adanya perkembangan psikososial siswa yang baik, seperti: siswa masih memilih-milih teman dan menghiraukan siswa lainnya, siswa masih malumalu untuk berkomunikasi dengan guru, dan pada saat peneliti melakukan wawancara dengan beberapa siswa tentang dirinya dan orang tuanya, ternyata komunikasi antara siswa dan orang tua kurang berjalan, seperti: orang tua tidak perduli terhadap kegiatan disekolah dan cenderung tidak perduli ketika siswa mendapatkan nilai yang kurang baik maupun baik.

Permasalahan yang berkaitan dengan perkembangan psikososial dan hasil belajar sebelumnya sudah pernah diteliti oleh Wibowo \& Susanto (2014) tentang Dinamika Dukungan Sosial pada Prestasi Siswa Sekolah Dasar Berbasis Pendekatan Indigenous Psychology. Menurutnya, siswa yang memperoleh dukungan sosial dari lingkungannya akan mempengaruhi prestasi belajar mereka. Penelitian lain yang cukup relevan juga telah dilakukan oleh Baidi (2014) tentang Pembelajaran PPKn Berbasis Multikuluralisme Perspektif Psikologi Sosial Islam. Menurutnya, keragaman bisa menimbulkan kerawanan konflik, untuk mencegah terjadinya konflik maka diperlukan perkembangan psikologi sosial yang baik. Pembelajaran PPKn memiliki relasi dengan Psikologi Sosial karena keragaman masyarakat merupakan suatu keniscayaan. Begitu pula penelitian yang dilakukan oleh Simanjutak (2017) tentang Pengaruh Sikap Sosial Siswa Terhadap Prestasi Belajar Pendidikan Kewarganegaraan. Menurutnya, kerap sekali timbul persepsi masyarakat yang menyatakan bahwa siswa-siswi yang tidak memiliki sikap sikap sosial akan berdampak buruk pada prestasi belajar disekolah. Sikap sosial ternyata berpengaruh positif dan signifikan terhadap prestasi belajar PPKn.

Oleh karena itu, untuk mengatasi permasalahan tersebut maka harus ada dukungan dari lingkungan sekitarnya (orangtua, teman sebaya, dan sekolah) sehingga tercipta perkembangan psikososial yang baik. Selain itu, pada saat pembelajaran PPKn guru harus menanamkan nilainilai moral yang dapat mempengaruhi pola pikir dan perilaku siswa agar bisa berprilaku yang dapat diterima di masyarakat (masyarakat lingkungan rumah dan sekolah), mampu memainkan peran sosial dimanapun berada, dan mampu bersikap sosial (antara individu satu dengan individu lain). Penelitian ini bertujuan untuk: (1) memperoleh data perkembangan psikososial, (2) 
memperoleh data hasil belajar PPKn di kelas IV B, (3) mengetahui seberapa besar pengaruh perkembangan psikososial terhadap hasil belajar PPKn di kelas IV B MIN Kota Cirebon.

\section{METODE PENELITIAN}

Metode yang digunakan dalam penelitian ini menggunakan pendekatan kuantitatif, karena penelitian ini menggunakan data penelitian berupa angka-angka dan analisis menggunakan statistik melalui SPSS. Desain penelitian yang digunakan dalam penelitian ini adalah Preeksperimental design. Bentuk Pre-eksperimental design dalam penelitian ini adalah One-Shot Case Study. Pada design ini suatu kelompok diberikan treatmen (perlakuan) khusus untuk selanjutnya di observasi hasilnya. (treatmen adalah sebagai variabel independen yaitu perkembangan psikososial, dan hasil belajar PPKn sebagai variabel dependen).

Penelitian ini dilakukan di MIN Kota Cirebon yang terletak di Jalan Samadikun Gang Bawal No. 142 A Rt 02 / Rw 10 Harjamukti Kota Cirebon. Penelitian ini dilaksanakan pada tanggal 05 Maret sampai dengan 05 Mei 2018. Populasi dalam penelitian ini adalah seluruh siswa kelas IV B MIN Kota Cirebon, dengan jumlah populasi sebanyak 20 orang siswa yang terdiri dari 7 laki-laki dan 13 perempuan. Penelitian ini menggunakan teknik sampling jenuh, dimana jumlah sampel sama saja dengan jumlah populasi. Sehingga sampel yang digunakan dalam penelitian ini sebesar 20 orang.

Teknik pengumpulan data dalam penelitian ini adalah (1) Angket. Kuesioner (angket) digunakan untuk menyelidiki dan mengetahui perkembangan psikososial siswa dengan mengajukan beberapa pernyataan berupa pernyataan positif dan negatif. Pada kuesioner ini, peneliti akan menggunakan skala likert, disajikan dalam bentuk checklist dengan menggunakan alternatif jawaban yaitu $\mathrm{Sl}=$ selalu, $\mathrm{Sr}=$ sering, $\mathrm{Kd}=$ kadang-kadang, dan $\mathrm{TP}=$ tidak pernah. (2) Tes. Tes yang digunakan dalam penelitian ini adalah tes bentuk pilihan ganda. Sebelum digunakan untuk penelitian, instrumen terdiri dari 20 soal kemudian diuji cobakan kepada siswa di kelas atas, guna mengukur validitas dan realibilitas. 20 soal setelah diuji cobakan ternyata yang terpakai hanya 10 soal yang dijadikan instrumen penelitian.

Sementara itu, teknik analisis data dalam penelitian ini adalah (1) analisis data angket. Pengolahan data angket dalam penelitian menggunakan rumus prosentase angket sebagai berikut: $\mathrm{P}=\frac{\mathrm{F}}{\mathrm{N}} \mathrm{X} 100 \%$, Keterangan: $\mathrm{P}=$ Presentase setiap kemungkinan jawaban, $\mathrm{F}=$ Frekuensi setiap kemungkinan jawaban, $\mathrm{N}=$ Jumlah responden, $100 \%$ = Standar hitung. (2) Uji Regresi. Uji Regresi bertujuan untuk mencari pengaruh perkembangan psikososial terhadap hasil belajar PPKn di kelas IV B MIN Kota Cirebon. 


\section{HASIL DAN PEMBAHASAN}

\section{Hasil Penelitian}

\section{Analisis Data Angket}

Berdasarkan hasil penelitian, berikut akan disajikan deskripsi data yang diperoleh dari hasil analisis instrumen angket terhadap perkembangan psikososial kepada 20 siswa kelas IV B MIN Kota Cirebon.

Tabel 1. Rekapitulasi Data Perkembangan Psikososial

\begin{tabular}{|c|c|c|c|c|c|c|c|c|c|c|}
\hline \multirow{3}{*}{$\begin{array}{c}\text { No. } \\
\text { Angket }\end{array}$} & \multicolumn{8}{|c|}{ Skor } & \multirow{2}{*}{\multicolumn{2}{|c|}{ JUMLAH }} \\
\hline & \multicolumn{2}{|r|}{1} & \multicolumn{2}{|c|}{2} & \multicolumn{2}{|r|}{3} & \multicolumn{2}{|r|}{4} & & \\
\hline & $\mathbf{F}$ & Skor & $\mathbf{F}$ & Skor & $\mathbf{F}$ & Skor & $\mathbf{F}$ & Skor & $\mathbf{F}$ & Skor \\
\hline 1 & 5 & 5 & 6 & 12 & 7 & 21 & 2 & 8 & 20 & 46 \\
\hline 2 & 0 & 0 & 12 & 24 & 8 & 24 & 0 & 0 & 20 & 48 \\
\hline 3 & 5 & 5 & 14 & 28 & 1 & 3 & 0 & 0 & 20 & 36 \\
\hline 4 & 5 & 5 & 8 & 16 & 6 & 18 & 1 & 4 & 20 & 43 \\
\hline 5 & 8 & 8 & 6 & 12 & 4 & 12 & 2 & 8 & 20 & 40 \\
\hline 6 & 1 & 1 & 6 & 12 & 3 & 9 & 10 & 40 & 20 & 62 \\
\hline 7 & 4 & 4 & 12 & 24 & 4 & 12 & 0 & 0 & 20 & 40 \\
\hline 8 & 2 & 2 & 14 & 28 & 4 & 12 & 0 & 0 & 20 & 42 \\
\hline 9 & 9 & 9 & 10 & 20 & 1 & 3 & 0 & 0 & 20 & 32 \\
\hline 10 & 0 & 0 & 9 & 18 & 2 & 6 & 9 & 36 & 20 & 60 \\
\hline 11 & 6 & 6 & 4 & 8 & 7 & 21 & 3 & 12 & 20 & 47 \\
\hline 12 & 7 & 7 & 5 & 10 & 7 & 21 & 1 & 4 & 20 & 42 \\
\hline 13 & 4 & 4 & 4 & 8 & 4 & 12 & 8 & 32 & 20 & 56 \\
\hline 14 & 4 & 4 & 4 & 8 & 9 & 27 & 3 & 12 & 20 & 51 \\
\hline 15 & 0 & 0 & 9 & 18 & 4 & 12 & 7 & 28 & 20 & 58 \\
\hline 16 & 0 & 0 & 9 & 18 & 4 & 12 & 7 & 28 & 20 & 58 \\
\hline Jumlah & 60 & 60 & 132 & 264 & 75 & 225 & 53 & 212 & 320 & 761 \\
\hline
\end{tabular}

Pada tabel 1 diperoleh informasi bahwa data yang diperoleh dari 20 responden dengan jumlah item angket sebanyak 16, maka skor ideal untuk variabel perkembangan psikososial adalah 20 responden x 16 item x 4 (skor tertinggi tiap item $)=1280$. Jumlah pencapaian skor hasil penyebaran angket adalah 761. Presentasi angket tentang perkembangan psikososial dapat dihitung dengan rumus: Standar skor tertinggi $x 100 \%$ Jadi, presentase pencapaian skor respon siswa adalah $\frac{761}{1280} \times 100 \%=59,4 \%$

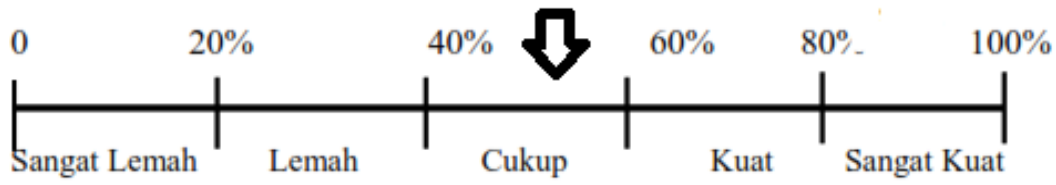

Grafik 1. Interpretasi Nilai Angket 
Berdasarkan grafik 1 menunjukkan bahwa skor tergolong pada kategori cukup berada di antara $40 \%$ - 60\%. Jumlah presentase pencapaian skor respon siswa pada perkembangan psikososial adalah 59,4\% dibulatkan menjadi 59\%. Maka termasuk dalam kategori cukup.

\section{Analisis Data Tes}

Untuk mengetahui hasil belajar PPKn, maka diberikan soal tes materi hak dan kewajiban sebanyak 10 soal berbentuk pilihan ganda yang diberikan kepada 20 siswa.

Tabel 2. Hasil Belajar PPKn

\section{Statistics}

\begin{tabular}{lrr}
\hline N & Valid & 20 \\
\cline { 2 - 3 } & Missing & 0 \\
\hline Mean & 62,50 \\
\hline Median & 70,00 \\
\hline Mode & $70^{\mathrm{a}}$ \\
\hline Minimum & 20 \\
\hline Maximum & 100 \\
\hline Sum & 1250 \\
\hline
\end{tabular}

a. Multiple modes exist. The smallest value is shown

Pada tabel 2 telihat bahwa dari jumlah responden sebanyak 20 siswa diperoleh mean (rata-rata) hasil belajar PPKn sebesar 62,50, median (nilai tengah) diperoleh sebesar 70, mode (nilai yang paling sering muncul) sebesar 70,00., minimum (nilai terkecil) sebesar 20 dan maximum (nilai terbesar) sebesar 100. Hal ini menunjukkan bahwa hasil belajar sebagaian besar siswa sudah memenuhi KKM yang ditentukan oleh pihak sekolah yakni 62. Untuk mempermudah dalam membaca data tersebut, berikut disajikan ke dalam grafik berikut.

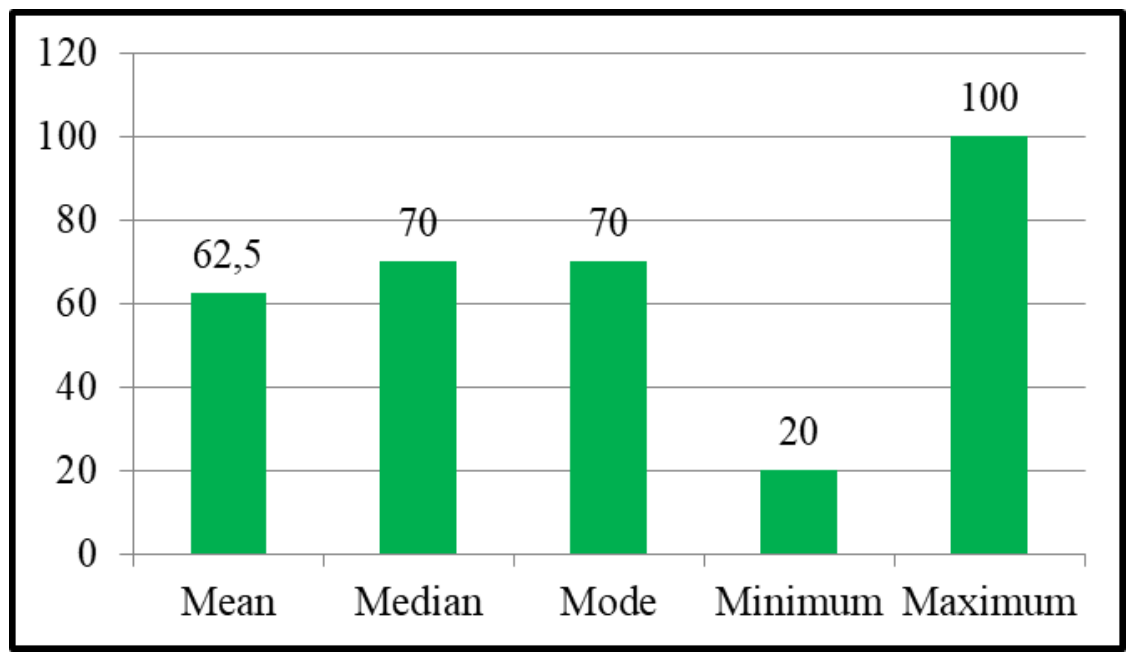

Grafik 2. Grafik Hasil Belajar PPKn di Kelas IV B MIN Kota Cirebon 


\section{Uji Hipotesis}

Adapun data hasil uji determinasi dapat disajikan sebagaimana tabel 3 berikut:

Tabel 3. Uji Determinasi

\begin{tabular}{lllll}
\hline Model & $\mathrm{R}$ & $\mathrm{R}$ Square & Adjusted R Square & Std. Error of the Estimate \\
\hline 1 &, $933^{\mathrm{a}}$ &, 871 &, 864 &, 862 \\
\hline
\end{tabular}

a. Predictors: (Constant), Perkembangan psikososial

Pada tabel 3 terlihat bahwa R Square $\left(\mathrm{r}^{2}\right)$ sebesar 0,871 (kuadrat dari koefisien korelasi). Nilai tersebut dapat digunakan untuk mengetahui besar kecilnya sumbangan variabel X (perkembangan psikososial) terhadap variabel Y (hasil belajar PPKn) dengan cara menghitung koefisien determinan (KD) menggunakan rumus sebagai berikut:

$\mathrm{KD}=\mathrm{r}^{2} \mathrm{X} 100 \%$

$\mathrm{KD}=0,871 \times 100 \%$

$\mathrm{KD}=87,1 \%$

Perhitungan tersebut mempunyai arti bahwa pengaruh perkembangan psikososial terhadap hasil belajar PPKn adalah $87,1 \%$ dan sisanya 12,9\% dipengaruhi faktor lain. Untuk mengetahui apakah pengaruhnya signifikan atau tidak, maka dapat dilihat pada tabel 4 berikut:

Tabel 4. Uji Koefisien Regresi

Coefficients $^{\mathrm{a}}$

\begin{tabular}{lcccccc}
\hline \multirow{2}{*}{ Model } & \multicolumn{2}{c}{$\begin{array}{c}\text { Unstandardized } \\
\text { Coefficients }\end{array}$} & $\begin{array}{c}\text { Standardized } \\
\text { Coefficients }\end{array}$ & \multirow{2}{*}{$\mathrm{T}$} & Sig. \\
\cline { 2 - 5 } & \multicolumn{2}{c}{ B } & Std. Error & Beta & & \\
\hline 1 & (Constant) & $-1,642$ &, 741 & & $-2,216$ &, 040 \\
\cline { 2 - 5 } & $\begin{array}{c}\text { Perkembangan } \\
\text { psikososial }\end{array}$ &, 207 &, 019 &, 933 & 11,029 &, 000 \\
\hline
\end{tabular}

a. Dependent Variable: Hasil belajar PPKn

Berdasarkan tabel 4 diketahui bahwa nilai constantnya ialah -1,642 dan nilai perkembangan psikososial ialah 0,207. Secara umum rumus persamaan regresi adalah: $Y$ $=\mathrm{a}+\mathrm{bX}$. Y adalah variabel dependent, dalam hal ini adalah hasil belajar PPKn, dan X adalah variabel independent, dalam hal ini adalah perkembangan psikososial. Sedangkan a dan $b$ adalah nilai konstanta yang dicari. Dari keterangan tersebut kita dapat memperoleh persamaan regresi sebagai berikut:

$\mathrm{Y}=\mathrm{a}+\mathrm{bX}$

$\mathrm{Y}=-1,642+0,207 \mathrm{X}$

Nilai konstanta dari koefisien regresi sebesar 1,642. Hal ini menyatakan bahwa jika tidak kenaikan nilai atau skor dari variabel perkembangan psikososial, maka variabel 
hasil belajar PPKn adalah -1,642. Koefisien regresi sebesar 0,207 menyatakan bahwa setiap terjadi penambahan skor variabel perkembangan psikososial akan dapat menambah kenaikan variabel hasil belajar PPKn. Berdasarkan hasil uji koefisien regresi tersebut diketahui bahwa nilai signifikansinya sebesar 0.000, $\mathrm{t}$ hitung sebesar 11,029 dan tabel sebesar 2,10982. Karena nilai signifikansinya lebih kecil dari 0,05 dan $t_{\text {hitung }}(11,029)$ lebih besar dari ttabel (2,10982), maka Ho ditolak. Artinya bahwa perkembangan psikososial berpengaruh signifikan terhadap hasil belajar PPKn di kelas IV b MIN Kota Cirebon.

\section{Pembahasan}

Berdasarkan hasil analisis angket yang disebar kepada 20 responden dengan jumlah 16 pernyataan, terdiri dari 8 pernyataan positif dan 8 pernyataan negatif didapatkan hasil yaitu $21 \%$ siswa menyatakan tidak pernah, 36\% menyatakan kadang-kadang, 28\% menyatakan sering dan 14\% siswa menyatakan selalu. Presentasi tersebut diperoleh dari jumlah frekuensi masingmasing alternatif jawaban ( $\mathrm{Sl}, \mathrm{Sr}, \mathrm{Kd}, \mathrm{TP}$ ) pada tiap item instrumen angket perkembangan psikososial. Jumlah pencapaian skor tertinggi adalah 1280. Sementara iru, pencapaian skor hasil penyebaran angket adalah sebesar 761. Sehingga didapatkan hasil jumlah presentasi pencapaian skor respon siswa adalah sebesar 59\%. Skor tersebut tergolong cukup kuat yang berada di antara $41 \%-60 \%$.

Hasil analisis tersebut menunjukan bahwa perkembangan psikososial siswa belum kuat, terlihat dari pencapaian skor respon siswa yang masih dalam kategori cukup. Hal ini digambarkan dari kurangnya komunikasi antara lingkungannya (orang tua, teman sebaya dan sekolah) berupa orang tua tidak pernah menanyakan nilai ulangan harian, nilai ujian tengah semester maupun nilai rapot yang didapatkan oleh siswa, kurangnya dukungan dari teman-teman sebaya dan kurangnya komunikasi antara guru dengan siswa. Padahal menurut (Yusuf, 2012) teman sebaya dan sekolah memegang peranan penting dalam perkembangan psikososial anak, karena tidak menutup kemungkinan anak akan berinteraksi dan tumbuh dalam lingkungan pertemanan, baik di sekolah maupun di luar sekolah.

Sementara itu, berdasarkan hasil analisis data hasil belajar PPKn siswa diketahui bahwa rata-rata hasil belajar PPKn siswa kelas IV B sebesar 62,5. Nilai tersebut telah melampaui kriteria ketuntasan minimal (KKM) mata pelajaran PPKn yang ditetapkan oleh pihak sekolah yakni sebesar 62. Selanjutnya, dari hasil analisis uji koefisien regresi diperoleh $t$ hitung sebesar 11,029 dan nilai signifikansi sebesar 0,000 serta $t_{\text {tabel }}$ sebesar 2,10982. Karena nilai signifikansinya lebih kecil dari 0,05 dan thitung $(11,029)$ lebih besar dari tabel $(2,10982)$ maka $\mathrm{H}_{0}$ ditolak, artinya bahwa perkembangan psikososial berpengaruh signifikan terhadap hasil belajar 
PPKn siswa kelas IV MIN Kota Cirebon. Besarnya pengaruh perkembangan psikososial terhadap hasil belajar PPKn siswa adalah sebesar 87,1\%, dan 12,9\% dipengaruhi oleh faktor lain.

Oleh karena itu, anak usia Sekolah Dasar harus lebih diperhatikan sehingga masa depan anak tersebut tidak mengalami hambatan dalam prestasi dan psikososial (Dudu, Kusuma, \& Widiani, 2016). Peran orang tua juga memiliki pengaruh terhadap perkembangan psikososial anak usia sekolah sehingga anak mampu menyelesaikan tugas (sekolah atau rumah yang diberikan). Orang tua dengan peran sebagai pemberi stimulus mampu mengarahkan anak untuk dapat berperilaku positif sehingga akan terbentuk perkembangan psikososial (Irmilia, Herlina, \& Hasneli, 2015). Faktor lain yang mempengaruhi perkembangan psikososial juga bisa berupa kematangan emosi dan percaya diri (Kristianawati \& Jalali, 2014), sehingga peserta didik di SD/MI mulai membentuk ikatan baru dengan teman sebaya dan mulai mampu menyesuaikan diri sendiri kepada sikap bekerjasama (Prastowo, 2014). Bentuk interaksi sosial dengan teman sebaya pada anak sekolah berupa permainan, obrolan, saling berkunjung ke rumah teman (Setiawati \& Suparno, 2010). Faktor-faktor lain yang mempengaruhi hasil belajar menurut (Oktavia \& Yulius, 2015) adalah status gizi, dan tingkat pendidikan Ibu. Selain itu, menurut (Murti \& Heryanto, 2016) kompetensi guru di sekolah dan daya dukung lingkungan masyarakat juga ikut mempengaruhi hasil belajar siswa. Adanya pengaruh perkembangan psikososial terhadap hasil belajar sejalan dengan pendapat Baron dan Byrne (2004) bahwa pemahaman yang diberikan oleh perspektif kognitif telah memberikan sumbangan besar pada pemahaman kita tentang berbagai aspek dari perilaku sosial dalam psikososial. Hasil penelitian ini juga didukung oleh hasil penelitiannya (Hardiyana, 2014), (Mulyanti \& Chundrayetti, 2017) yang mengungkapkan bahwa perkembangan psikososial berpengaruh terhadap hasil belajar PPKn dan perkembangan anak.

\section{SIMPULAN}

Berdasarkan uraian hasil penelitian dapat disimpulkan hal-hal sebagai berikut:

1. Respon siswa terhadap perkembangan psikososial adalah 59\%, skor tersebut tergolong cukup kuat yang berada di antara $41 \%-60 \%$.

2. Nilai rata-rata hasil belajar PPKn siswa sebesar 62,5. Nilai tersebut telah melampaui kriteria ketuntasan minimal (KKM) mata pelajaran PPKn yang ditetapkan oleh pihak sekolah yakni sebesar 62.

3. Berdasarkan hasil uji koefisien regresi diketahui bahwa thitung sebesar 11,029 lebih besar dari $\mathrm{t}_{\text {tabel }}$ sebesar 2,10982, maka $\mathrm{H}_{0}$ ditolak. Artinya bahwa perkembangan psikososial berpengaruh terhadap hasil belajar PPKn. Besarnya pengaruh perkembangan psikososial terhadap hasil belajar PPKn sebesar $87,1 \%$, dan sisanya $12,9 \%$ dipengaruhi oleh faktor lain. 


\section{DAFTAR PUSTAKA}

Baidi. (2014). Pembelajaran PKn Berbasis Multikuluralisme Perspektif Psikologi Sosial Islam. Ulil Albab, 15(2), 169-187.

Baron, R. A., \& Byrne, D. (2004). Psikologi Sosial. Jakarta: Erlangga.

Burhaein, E. (2017). Aktivitas Fisik Olahraga untuk Pertumbuhan dan Perkembangan Siswa SD. Indonesian Journal of Primary Education, 1(1), 51-58.

Desmita. (2015). Psikologi Perkembangan. Bandung: Remaja Rosdakarya.

Dudu, Y., Kusuma, F. H., \& Widiani, E. (2016). Hubungan Pola Asuh Orang Tua dengan Perkembangan Psikososial Tahap Industry Vs Inferiority Anak Usia Sekolah $(6-12$ Tahun) Di Sdn Tlogomas 1 Kecamatan Lowokwaru Malang. Nursing News, 1(2), 180189.

Hardiyana, S. (2014). Pengaruh Guru PPkn Terhadap Pembentukan Karakter Siswa. Jurnal Ilmiah PPKn Ikip Veteran Semarang, 2(1), 54-64.

Irmilia, E., Herlina, \& Hasneli, Y. (2015). Hubungan Peran Orang Tua Terhadap Perkembangan Psikososial Anak Usia Sekolah. JOM, 2(1), 551-557.

Kristianawati, E., \& Jalali, M. A. (2014). Hubungan Antara Kematangan Emosi Dan Percaya Diri. Persona; Jurnal Psikologi Indonesia, 3(3), 247-252.

Mulyanti, S., \& Chundrayetti, E. (2017) Hubungan Stimulasi Psikososial dengan Anak Perkembangan. Jurnal Kesehatan Andalas, 6(2), 340-344

Murti, S., \& Heryanto. (2016). Pengaruh Kualitas Interaksi Sosial Di Lingkungan Keluarga Terhadap Prestasi Belajar Siswa. Al Ibtida: Jurnal Pendidikan Guru MI, 3(2), 253-268.

Oktavia, N. S., \& Yulius, O. Y. (2015). Faktor-faktor yang Berhubungan dengan prestasi belajar Pada Siswa Sekolah Dasar Negeri 47 Korong Gadang Kecamatan Kuranji Kota Padang Tahun 2014. Jurnal Ipteks Terapan, 8(3), 74-82

Prastowo, A. (2014). Pemenuhan Kebutuhan Psikologis Peserta Didik SD/MI melalui Pembelajaran Tematik-Terpadu. JPSD: Jurnal Pendidikan Sekolah Dasar, 1(1), 1-13.

Santrock, J. W. (2011). Masa Pekembangan Anak (Children). Jakarta: Salemba Humanika.

Setiawati, E., \& Suparno. (2010). Interaksi Sosial dengan Teman Sebaya Pada Anak Homeschooling dan Anak Sekolah Reguler. Indigenous; Jurnal Ilmiah Berkala Psikologi, 12(1), 55-65.

Simanjutak, M. (2017). Pengaruh Sikap Sosial Siswa terhadap Prestasi Belajar Pendidikan Kewarganegaraan. Prosiding Seminar Nasional Tahunan Fakultas Ilmu Sosial Universitas Negeri Medan, (pp. 122-126).

Soetjiningsih, C. H. (2014). Perkembangan Anak Sejak Pembuahan Sampai dengan Kanakkanak Akhir. Jakarta: Prenadamedia Group.

Susanto, A. (2016). Teori Belajar \& Pembelajaran di Sekolah Dasar. Jakarta: Prenadamedia Group. 
Latifah, Dwi Anita Alfiani, Andini, Pengaruh Perkembangan Psikososial...

Wibowo, M. W., \& Susanto, D. Y. (2014). Dinamika Dukungan Sosial pada Prestasi SiswaSekolah Dasar Berbasis Pendekatan Indigenous Psychology. Jurnal Psikologi Tabularasa, 9(1), 30-36.

Yusuf, S. (2012). Psikologi Perkembangan Anak \& Remaja. Bandung: Remaja Rosdakarya. 